\title{
Efisiensi Usaha dan Tingkat Kesejahteraan Pengrajin Tape Ketan Di Kabupaten Kuningan
}

\author{
Devin Ellardo Damara, Dijan Rahajuni, Goro Binardjo* \\ Fakultas Ekonomi dan Binis, Universitas Jenderal Soedirman \\ Correspondence email: goro.binardjo@unsoed.ac.id
}

\begin{abstract}
Abstrak. Penelitian ini bertujuan untuk menganalisis efisiensi usaha dari pengrajin tape ketan dan mengetahui tingkat kesejahteraan dari pengrajin tape ketan di Kecamatan Cibeureum Kabupaten Kuningan. Jumlah responden pada penelitian ini sebanyak 32 orang dengan menggunakan metode sensus. Adapun teknik pengambilan data diperoleh secara langsung dari responden melalui observasi dan wawancara dengan kuesioner. Metode analisis yang digunakan dalam penelitian ini adalah analisis efisiensi usaha menggunakan analisis R/C Rasio, sedangkan untuk analisis tingkat kesejahteraannya dengan cara membandingkan pendapatan perkapita perbulan dari keluarga pengrajin tape ketan dengan Upah Minimum Kabupaten (UMK) yang berlaku di Kabupaten Kuningan. Hasil dari penelitian ini menunjukkan bahwa nilai R/C Rasio dari usaha tape ketan di Kecamatan Cibeureum Kabupaten Kuningan adalah sebesar 1,62. Nilai R/C Rasio yang lebih besar dari satu artinya usaha tersebut sudah efisien serta menguntungkan dan layak untuk dikembangkan. Sebagian besar dari keluarga pengrajin tape ketan di Kecamatan Cibeureum Kabupaten Kuningan dapat dikatakan sejahtera karena pendapatan perkapita per bulan sudah lebih besar daripada UMK yang berlaku di Kabupaten Kuningan.
\end{abstract}

Kata Kunci: Tape Ketan; Efisiensi Usaha; Tingkat Kesejahteraan

Abstract. This research aims to analyze the business efficiency of the ketan tape craftsmen and to determine the level of welfare of the ketan tape craftsmen in Cibeureum District, Kuningan Regency. The number of respondents in this study were 32 people using the census method. The data collection techniques were obtained directly from respondents through observation and interviews with questionnaires.The analytical method used in this research is business efficiency analysis using $R$ / C Ratio analysis, while for the analysis of the level of welfare by comparing the monthly income per capita of the tape ketan craftsman's family with the Regency Minimum Wage (UMK) in Kuningan RegencyThe results of this research indicate that the $R / C$ ratio value of the ketan tape business in Cibeureum District, Kuningan Regency is 1.62. An R / C Ratio value that is greater than one means that the business is efficient and profitable and feasible to develop. Most of the ketan tape craftsmen families in Cibeureum District, Kuningan Regency can be said to be prosperous because the income per capita per month is already greater than the UMK prevailing in Kuningan Regency.

Keywords: Tape Ketan; Business Efficiency; Level of Welfare

\section{PENDAHULUAN}

Tape ketan merupakan makanan khas dari Kuningan. Usaha tape ketan di Kabupaten Kuningan sudah ada sejak tahun 1970. Kecamatan Cibeureum merupakan sentra produksi tape ketan yang paling terkenal di Kabupaten Kuningan. Tape ketan pada awalnya merupakan makanan wajib di Hari Raya dan belum menjadi usaha seperti saat ini. Seiring dengan kemajuan zaman masyarakat menyadari akan besarnya peluang bisnis tape ketan tersebut, hingga usaha tape ketan menjadi usaha turun temurun dan mampu menjadi usaha yang menyediakan lapangan kerja sekaligus menjadi kekuatan lokal daerahnya. Usaha tape ketan ini telah memberikan kesempatan kerja terhadap masyarakat sekitar industri ini. Rata-rata tenaga kerja yang bekerja di usaha tape ketan ini merupakan keluarga, saudara dan tetangga yang dekat dengan tempat produksinya. Sehingga tidak heran usaha tape ketan ini jumlahnya selalu meningkat.

Menurut data dari Dinas Koperasi UKM Perdagangan dan Perindustrian Kabupaten Kuningan, jumlah usaha tape ketan di Kecamatan Cibeureum tahun
2017 sebanyak 35 unit. Tahun 2018 naik menjadi 37 unit, lalu pada tahun selanjutnya menjadi 40 unit. Peningkatan ini terjadi karena tenaga kerja pada usaha tape ketan ini membuat produksi sendiri setelah memiliki modal yang cukup. Usaha tape ketan ini dalam proses produksinya masih menggunakan teknologi yang masih sederhana. Penggunaan peralatan tradisional bertujuan untuk menjaga cita rasa, kualitas dan keaslian dari tape ketan itu sendiri. Pengelolaan manajemen usaha tape ketan selama ini belum dijalankan secara baik.

Permasalahan yang dihadapi industri rumah tangga tape ketan di Kecamatan Cibereum adalah belum adanya sistem manajemen usaha untuk menghitung keuntungan dan kerugian dari usahanya, promosi tidak secara aktif dilakukan oleh industri, terbatasnya modal yang digunakan. Dari sisi pesaing sudah banyak industri rumah tangga yang memproduksi tape ketan di Kuningan (Rahmawati, 2019). Setiap usaha pasti bertujuan untuk mendapatkan pendapatan yang maksimal. Cara untuk meningkatkan pendapatan 
tersebut yakni dengan memaksimalkan penjualan dan meminimalisir biaya produksi yang dipakai.

Efisiensi usaha memiliki hubungan erat dengan pendapatan. Semakin efisien suatu usahan, maka semakin besar pendapatan yang akan diterima. Pendapatan yang dihasilkan oleh pengrajin tape ketan digunakan untuk memenuhi kebutuhan keluarganya. Pendapatan merupakan salah satu indikator untuk mengetahui tingkat kesejateraan suatu keluarga, dimana semakin tinggi pendapatan maka tingkat kesejahteraannya akan semakin lebih baik. Sejahtera adalah kondisi masyarakat yang terpenuhi kebutuhan dasarnya. Kebutuhan dasar tersebut berupa kecukupan dan mutu sandang, pangan, papan, kesehatan, pendidikan, lapangan pekerjaan, dan kebutuhan dasar lainnya seperti lingkungan yang bersih, aman, dan nyaman (Kanah, 2015). Dengan demikian pertanyaan penelitiannya adalah 1) Bagaimana tingkat efisiensi usaha pengrajin tape ketan di Kecamatan Cibeureum?; 2) Bagaimana tingkat kesejahteraan pengrajin tape ketan di Kecamatan Cibeureum? Adapun tujuan dari penelitian ini yakni 1) Untuk menganalisa efisiensi usaha pengrajin tape ketan di Kecamatan Cibeureum; 2) Untuk menganalisa tingkat kesejahteraan pengrajin tape ketan di Kecamatan Cibeureum.

\section{METODE}

Metode yang digunakan dalam penelitian ini ialah survey. Penelitian dilaksanakan di Kecamatan Cibeureum, Kabupaten Kuningan, Jawa Barat pada bulan Agustus- September 2020. Subjek penelitian ini adalah pengrajin tape ketan di Kecamatan tersebut. Pengambilan sampel petani dilakukan dengan cara sensus dimana semua populasi diambil menjadi sampel dan dijadikan sebagai responden (Effendi, 2012). Sampel yang akan digunakan pada penelitian ini sebanyak 32 pengrajin tape ketan. Teknik pengambilan data diambil dari penelitian ini meliputi 1) teknik kuesioner yakni cara mengumpulkan data dan informasi dengan cara menanyakan melalui sekumpulan pertanyaan yang tertulis dalam kuesioner yang diberikan kepada pengrajin tape ketan, 2) teknik wawancara yakni suatu cara dalam mengumpulkan data dengan cara menanyakan secara langsung kepada responden yaitu pengrajin tape ketan, dan 3) Studi pustaka yaitu suatu data teori-teori yang ada hubungannya dengan masalah atau hal yang akan diteliti. Analisis data yang digunakan dalam metode ini yakni analisis efisiensi usaha dan analisis kelayakan usaha. Berikut adalah analisisnya :

Analisis Efisiensi Usaha yang meliputi

\section{Analisis Biaya}

$\mathrm{TC}=\mathrm{TFC}+\mathrm{TVC}$

Dimana:
$\mathrm{TC}=$ Total Cost (biaya total)

TFC = Total Fixed Cost (biaya tetap total), terdiri dari: Biaya Penyusutan Alat dan Biaya Pajak

TVC = Total Variable Cost (biaya variabel total), terdiri dari: Biaya Bahan Baku, dan Biaya lain-lain (Suratiyah, 2015)

\section{Analisis Penerimaan dan Pendapatan}

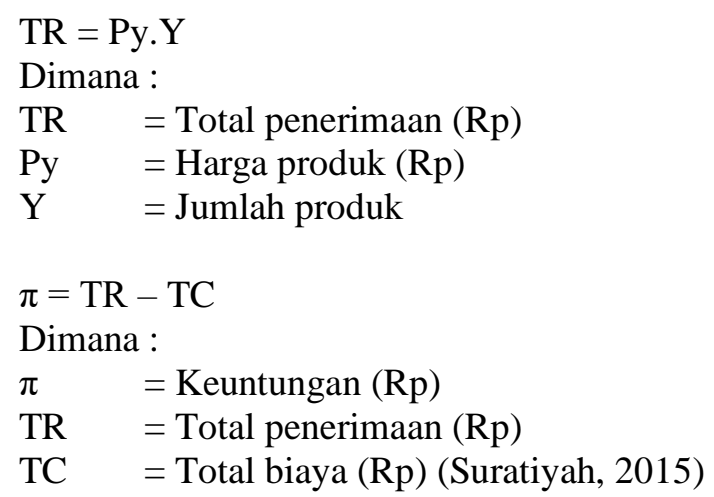

\section{Analisis R/C Ratio}

$\mathrm{R} / \mathrm{C}=\frac{T R}{T C}$

Keterangan kriteria sebagai berikut :

a. R/C > 1 berarti setiap tambahan biaya yang dikeluarkan akan menghasilkan tambahan penerimaan yang lebih besar daripada tambahan biayanya. Kegiatan usaha tape ketan menguntungkan.

b. $\mathrm{R} / \mathrm{C}=1$ berarti kegiatan usaha tape ketan berada pada posisi tidak untung dan tidak rugi.

c. $\mathrm{R} / \mathrm{C}<1$ berarti setiap tambahan biaya yang dikeluarkan akan menghasilkan tambahan penerimaan yang lebih kecil daripada tambahan biayanya. Kegiatan usaha tape ketan tidak menguntungkan (Soekartawi, 1995)

\section{Analisis Tingkat Kesejahteraan}

Kesejahteraan dari suata usaha dapat dilihat dengan menggunakan indikator Kebutuhan Hidup Layak (KHL) dan Upah Minimum Kabupaten/Kota (UMK) yang ditetapkan oleh pemerintah (Arifin, 2014). Tingkat kesejahteraan pengrajin tape ketan diukur dengan cara membandingkan pendapatan pengrajin dari usaha tape ketan dengan UMK Kabupaten Kuningan yang dasar penetapannya berdasarkan dari Kebutuhan Hidup Layak (KHL). Pendapatan dibedakan menjadi dua yakni pendapatan atas usaha tape ketan dan pendapatan total keluarga. Pendapatan total keluarga didapat dengan cara menambahkan pendapatan atas usaha tape ketan dan pendapatan lain diluar pendapatan tersebut (pendapatan usaha lain dan pendapatan anggota keluarga lain). Pendapatan per kapita didapat dari rumus : 


\section{Pendapatan Per Kapita atas pendapatan tape ketan $=\frac{\text { Pendapatan Usaha Tape Ketan }}{\text { Jumlah Anggota Keluarga }}$}

Pendapatan Per Kapita atas pendapatan total $=\frac{\text { (Pendapatan Usaha Tape Ketan }+ \text { Pendapatan lain) }}{\text { Jumlah Anggota Keluarga }}$

KHL sendiri besarannya berdasar pada kebutuhan sandang, pangan, papan, kesehatan, pendidikan, dan sebagainya. KHL bukan satu satunya faktor yang dipertimbangkan dalam penetapan upah minimum, masih ada empat faktor lain yaitu produktivitas, pertumbuhan ekonomi, kemampuan usaha marginal dan kondisi pasar kerja (Mahila, 2017). Pada penelitian Virginanda (2015) UMK berpengaruh terhadap kesejahteraan tenaga kerja. Sehingga UMK bisa dijadikan indikator kesejahteraan pengrajin tape ketan. Berdasarkan Surat Edaran Nomor:56/175/Yanbangsos tentang Pelaksanaan Upah Minimum Kabupaten/Kota di Daerah Provinsi Jawa Barat Tahun 2020 UMK Kabupaten Kuningan sebesar Rp1.882.642,36

Perbandingan pendapatan per kapita dengan UMK Kabupaten Kuningan : a. Pendapatan per kapita (atas pendapatan tape ketan/ pendapatan total) $\leq$ UMK Kabupaten Kuningan (Rp1.882.642,36) artinya pengrajin tape ketan belum sejahtera

b. Pendapatan per kapita (atas pendapatan tape ketan/ pendapatan total) > UMK Kabupaten Kuningan (Rp1.882.642,36) artinya pengrajin tape ketan belum sejahtera

\section{HASIL DAN PEMBAHASAN Analisis Efisiensi Usaha}

Setelah melakukan pengolahan data dan perhitungan data, maka diperoleh hasil analisis sebagai berikut:

Tabel 1. Biaya Tetap Pengrajin Tape Ketan di Kecamatan Cibeureum Tahun 2020

\begin{tabular}{lccr}
\hline \multicolumn{1}{c}{ Biaya } & Total Biaya/Bulan & Rata-rata Biaya/Bulan & Persentase $(\%)$ \\
& $(\mathrm{Rp})$ & 5.490 & 1,34 \\
PBB & 175.667 & 40.365 & 9,87 \\
Sertifikasi Halal & 1.291 .667 & 362.929 & 88,79 \\
Penyusutan Peralatan & 11.613 .722 & 408.783 & 100,00 \\
\hline \multicolumn{1}{c}{ Jumlah } & 13.081 .056 & & 2 \\
\hline
\end{tabular}

Sumber: Data Primer diolah, 2020

Biaya tetap adalah biaya yang besarannya tetap konstan tidak terpengaruh adanya perubahan dalam jumlah produksi tape ketan. Yang termasuk ke dalam biaya tetap ini adalah Pajak Bumi dan Bangunan (PBB), Sertifikasi Halal, dan penyusutan peralatan usaha tape ketan. Berdasarkan Tabel 1. total dari biaya tetap yang dikeluarkan oleh pengrajin tape ketan di Kecamatan Cibeureum adalah Rp13.081.056 dengan rata-rata tiap pengrajin tape ketan mengeluarkan biaya tetap sebesar Rp408.783. Kontribusi terbanyak terhadap biaya tetap adalah biaya penyusutan peralatan sebesar $88,79 \%$ sementara itu kontribusi yang terkecil sebesar 1,34\% dari biaya Pajak Bumi dan Bangunan (PBB) terhadap biaya tetap yang dikeluarkan pengrajin untuk usaha tape ketan ini.

Tabel 2. Biaya Variabel Usaha Tape Ketan di Kecamatan Cibeureum dalam Satu Bulan Tahun 2020

\begin{tabular}{clcrr}
\hline No. & \multicolumn{1}{c}{ Biaya } & Total Biaya/Bulan $(\mathrm{Rp})$ & Rata rata Biaya/Bulan $(\mathrm{Rp})$ & Persentase $(\%)$ \\
\hline 1. & Biaya Bahan Baku & 1.090 .894 .000 & 34.090 .438 & 63,28 \\
2. & Biaya Tenaga Kerja & 186.170 .000 & 5.817 .813 & 10,80 \\
3. & Biaya Kemasan & 338.160 .000 & 10.567 .500 & 19,61 \\
4. & Biaya Pengiriman & 86.140 .000 & 2.691 .875 & 5,00 \\
5. & Biaya Listrik \& Air & 15.650 .000 & 489.063 & 0,91 \\
6. & Biaya Pph & 7.025 .000 & 219.531 & 0,41 \\
\hline \multicolumn{7}{r}{ Jumlah } & 1.724 .039 .000 & 53.876 .219 & 100,00 \\
\hline
\end{tabular}

Sumber: Data Primer diolah, 2020

Biaya variabel adalah biaya yang dikeluarkan oleh pengrajin tape ketan dalam proses produksi dan berpengaruh terhadap jumlah output yang dihasilkan. Biaya variabel terdiri dari biaya bahan baku, biaya tenaga kerja, biaya kemasan, biaya pengiriman, biaya listrik \& air dan biaya Pajak Penghasilan (Pph). Berdasarkan Tabel. 2 dijelaskan bahwa total biaya variabel yang dikeluarkan oleh 32 pengrajin tape ketan di Kecamatan Cibeureum yaitu sebesar Rp1.724.039.000. Sementara pengeluaran biaya variabel 
per pengrajin tape ketan sebesar Rp53.876.219 untuk satu bulan produksi tape ketan di Kecamatan Cibeureum. Kontribusi terbanyak terhadap biaya variabel adalah biaya bahan baku yakni $63,28 \%$ sementara itu kontribusi yang terkecil sebesar $0,41 \%$ dari biaya $\mathrm{PPh}$ terhadap biaya tetap yang dikeluarkan pengrajin untuk usaha tape ketan ini.

Tabel 3. Penerimaan Pengrajin Tape Ketan dalam Satu Bulan.

\begin{tabular}{clcccrc}
\hline \multirow{2}{*}{ No. } & Penerimaan & Total & Harga Rata-rata $(\mathrm{Rp})$ & Total Penerimaan $(\mathrm{Rp})$ & Rata-rata(Rp) & Persentase $(\%)$ \\
\hline 1. & Ember Besar & 19.360 & 68.037 & 1.317 .200 .000 & 41.162 .500 & 46,93 \\
2. & Ember Kecil & 17.360 & 58.450 & 1.014 .700 .000 & 31.709 .375 & 36,15 \\
3. & Toples & 7.560 & 44.947 & 339.800 .000 & 10.618 .750 & 12,11 \\
4. & Mika & 11.000 & 12.273 & 135.000 .000 & 4.218 .750 & 4,81 \\
\hline \multicolumn{7}{r}{} \\
\hline
\end{tabular}

Sumber: Data Primer diolah, 2020

Penerimaan yang diterima oleh pengrajin tape ketan didapat dari hasil perkalian dari jumlah produksi tape ketan dengan harga tape ketan yang sudah ditetapkan. Besarnya penerimaan yang diperoleh tergantung dari produktivitas dan harga yang berlaku dipasar. Produk yang dihasilkan oleh pengrajin tape ketan di Kecamatan Cibeureum Kabupaten Kuningan dibedakan menjadi 4 kemasan yakni ember besar, ember kecil, toples, dan mika. Berdasarkan Tabel.3 total penerimaan 32 pengrajin tape ketan selama satu bulan yakni Rp2.806.700.000. Penerimaan rata-rata per pengrajin tape ketan dalam satu bulan sebesar Rp87.709.375. Penerimaan tertinggi didapat dari penjualan tape ketan dengan kemasan ember besar dengan rata- rata penerimaan sebesar Rp41.162.500 atau sebesar $46,93 \%$ dari rata-rata penerimaan per pengrajin. Sementara penerimaan terkecil didapat dari penjualan tape ketan dengan kemasan mika dengan rata-rata penerimaan Rp4.218.750 atau hanya sebesar 4,81\% dari rata-rata penerimaan per pengrajin tape ketan.

Tabel 4. Biaya, Penerimaan dan Efisiensi Usaha Tape Ketan

\begin{tabular}{lrr}
\hline Uraian & Rata Rata & \multicolumn{1}{l}{ Jumlah } \\
\hline Penerimaan & 41.162 .500 & 1.317 .200 .000 \\
1. Ember Besar & 31.709 .375 & 1.014 .700 .000 \\
2. Ember Kecil & 10.618 .750 & 339.800 .000 \\
3. Toples & 4.218 .750 & 135.000 .000 \\
4. Mika & $\mathbf{8 7 . 7 0 9 . 3 7 5}$ & $\mathbf{2 . 8 0 6 . 7 0 0 . 0 0 0}$ \\
\hline \multicolumn{1}{l}{ Total Penerimaan } & & \\
\hline Biaya & & \\
Biaya Tetap & 5.490 & 175.667 \\
1. Biaya PBB & 40.365 & 1.291 .667 \\
2. Sertifikasi Halal & 362.929 & 11.613 .722 \\
3. Penyusutan Peralatan & 408.783 & 13.081 .056 \\
\hline Sub Total & & \\
\hline Biaya Variabel & 34.090 .438 & 1.090 .894 .000 \\
1. Biaya Bahan Baku & 5.817 .813 & 186.170 .000 \\
2. Biaya Tenaga Kerja & 10.567 .500 & 338.160 .000 \\
3. Biaya Kemasan & 2.691 .875 & 86.140 .000 \\
4. Biaya Pengiriman & 489.063 & 15.650 .000 \\
5. Biaya Listrik \& Air & 219.531 & 7.025 .000 \\
6. Biaya Pph & 53.876 .219 & 1.724 .039 .000 \\
\hline Sub Total & $\mathbf{5 4 . 2 8 5 . 0 0 2}$ & $\mathbf{1 . 7 3 7 . 1 2 0 . 0 5 6}$ \\
\hline Total Biaya & $\mathbf{1 , 6 2}$ & $\mathbf{1 , 6 2}$ \\
\hline R/C Rasio & & \\
\hline
\end{tabular}

Sumber: Data Primer diolah, 2020
Total penerimaan dalam satu bulan yang di terima oleh 32 pengrajin tape ketan di Kecamatan Cibeureum adalah Rp2.806.700.000 dengan rata-rata tiap pengrajin Rp87.709.375. Sementara total biaya yang dikeluarkan untuk memproduksi tape ketan dalam satu bulan oleh 32 pengrajin tape ketan yaitu Rp1.737.120.056 dengan rata-rata biaya yang dikeluarkan tiap pengrajin sebesar Rp54.285.002. Oleh karenanya hasil perhitungan diatas menunjukkan bahwa nilai R/C Rasio dari usaha tape ketan di Kecamatan Cibeureum sebesar 1,62 hal ini artinya bahwa nilai R/C 1,62>1 berarti setiap tambahan biaya sebesar Rp. 1,00 yang dikeluarkan akan menghasilkan tambahan sebesar Rp. 1,62 yang lebih besar daripada tambahan biayanya. Sehingga usaha tape ketan di Kecamatan Cibeureum bisa dikatakan efisien dan menguntungkan serta layak untuk dikembangkan lagi.

Berdasarkan hasil analisis, pengrajin tape ketan di Kecamatan Cibeuruem Kabupaten Kuningan memperoleh pendapatan rata-rata Rp33.107.499 tiap bulannya. . Salah satu cara untuk mengetahui efisiensi usaha dengan perhitungan R/C rasio (Rahardi, 1999). Nilai R/C rasio dari usaha tape ketan sebesar 1,62 artinya usaha tersebut sudah efisien serta menguntungkan dan layak untuk dikembangkan. Hal ini sejalan dengan penelitian dari Nurhayati (2019) dimana hasil penelitiannya yaitu dengan rata-rata pendapatan Rp37.500.000 dan nilai R/C rasionya sebesar 1,6, maka usaha tape singkong di Desa Candi Binangun Kecamatan Sukorejo sudah efisien karena nilai R/C rasionya lebih besar dari 1 . Usaha tape ketan merupakan penghasilan utama dari pengrajin di Kecamatan Cibeureum. Usaha tape ketan sudah secara turun temurun dilakukan sehingga sudah berlangsung lama. Usaha ini layak dikembangkan lagi karena dapat menyerap tenaga kerja dari masyarakat sekitar. Tape ketan ini juga merupakan makanan khas Kabupaten Kuningan yang biasanya menjadi buah tangan orang orang untuk dibawa ke daerahnya masing-masing, sehingga Kabupaten Kuningan bisa lebih dikenal didaerah lain. Hal ini bisa menjadi daya tarik orangorang untuk datang ke Kuningan. 


\section{Analisis Kesejahteraan}

Kesejahteraan merupakan keadaan dimana pengrajin dapat dikatakan mempunyai kehidupan yang layak. Kesejahteraan erat hubungannya degan pendapatan, dimana pendapatan pengrajin tape ketan dibandingkan dengan UMK untuk mengetahui tingkat kesejahteraannya. Terdapat dua jenis pendapatan yang dibandingkan dengan UMK yakni pendapatan per kapita atas pendapatan usaha tape ketan dan pendapatan per kapita atas pendapatan total keluarga.

Tabel 5. Pendapatan per Kapita Pengrajin Tape Ketan atas Usaha Tape Ketan

\begin{tabular}{|c|c|c|c|}
\hline No. & Pendapatan per Kapita (Rp) & Responden & Persentase \\
\hline 1. & $891.778 \mathrm{~s} / \mathrm{d} \quad 4.273 .143$ & 6 & 18,75 \\
\hline 2. & $4.273 .143 \mathrm{~s} / \mathrm{d} \quad 7.654 .507$ & 7 & 21,88 \\
\hline 3. & $7.654 .508 \mathrm{~s} / \mathrm{d} 11.035 .872$ & 6 & 18,75 \\
\hline 4. & $11.035 .873 \mathrm{~s} / \mathrm{d} 14.417 .237$ & 7 & 21,88 \\
\hline 5. & $14.417 .238 \mathrm{~s} / \mathrm{d} 17.798 .602$ & 2 & 6,24 \\
\hline \multirow[t]{2}{*}{6.} & $17.798 .603 \mathrm{~s} / \mathrm{d} 21.179 .968$ & 4 & 12,50 \\
\hline & Jumlah & 32 & 100,00 \\
\hline
\end{tabular}

Sumber: Data Primer diolah, 2020

Untuk melihat kesejahteraan keluarga dari pengrajin tape ketan di Kecamatan Cibeureum dapat diketahui dengan cara membandingkan pendapatan per kapita keluarga dengan UMK Kabupaten Kuningan sebesar Rp1.882.642,36. Berdasarkan Tabel 5. Terdapat enam rentang pendapatan yang membedakan pengrajin tape ketan berdasarkan pendapatan per kapita atas pendapatan usaha tape ketan. Terdapat dua rentang pendapatan per kapita atas usaha tape ketan dengan jumlah pengrajin terbanyak sebesar 7 pengrajin atau setara dengan $21,88 \%$ yakni rentang pendapatan Rp4.273.143 sd Rp7.654.507 dan rentang pendapatan perkapita antara Rp11.035.873 sd Rp14.417.237. Terdapat 2 responden atau setara dengan $6,24 \%$ dengan pendapatan per kapita pengrajin tape ketan atas usaha tape ketan yang berada dalam rentang pendapatan sebesar Rp14.417.238 s/d Rp17.798.602. Secara keseluruhan berdasarkan perhitungan pada rata-rata pendapatan per kapita 32 pengrajin tape ketan atas pendapatan usaha tape ketan adalah sebesar Rp 9.702.347 yang dibandingkan dengan UMK Kabupaten Kuningan maka rata-rata pengrajin tape ketan di Kecamatan Cibeureum sudah sejahtera karena pendapatan per kapita atas usaha tape ketan sudah melebihi UMK yang berlaku.

Tabel 6. Tingkat Kesejahteraan Responden atas Usaha Tape Ketan

\begin{tabular}{cccc}
\hline No. & Uraian & Jumlah Responden & Persentase \\
\hline 1. & Sejahtera & 30 & 93,75 \\
2. & Tidak Sejahtera & 2 & 6,25 \\
\hline & Jumlah & 32 & 100,00 \\
\hline
\end{tabular}

Sumber: Data Primer diolah, 2020

Persentase tingkat kesejahteraan pengrajin tape ketan berdasar pendapatan per kapita atas pendapatan usaha tape ketan tersaji dalam Tabel 6. Terdapat dua kategori pengrajin tape ketan yakni pengrajin tape ketan yang sudah berada pada kondisi sejahtera dan kondisi belum sejahtera. Sebanyak 2 pengrajin tape ketan atau sebesar $6,25 \%$ yang berada pada kondisi belum sejahtera karena pendapatan per kapita atas pendapatan usaha tape ketan kedua pengrajin tersebut kurang dari UMK Kabupaten Kuningan. Sementara itu 30 pengrajin tape ketan lainnya atau setara dengan 93,75\% dapat dinyatakan berada pada kondisi sejahtera karena pendapatan per kapita atas pendapatan usaha tape ketan lebih besar dari UMK yang berlaku di Kabupaten Kuningan. Sehingga dapat disimpulkan bahwa sebagian besar pengrajin tape ketan di Kecamatan Cibeureum sudah berada pada kondisi sejahtera berdasarkan pendapatan per kapita atas pendapatan usaha tape ketannya.

Tabel 7. Pendapatan per Kapita Keluarga Pengrajin Tape Ketan atas Pendapatan Total Keluarga

\begin{tabular}{|c|c|c|c|}
\hline No. & Pendapatan per Kapita (Rp) & Responden & Persentase \\
\hline 1. & $1.558 .444 \mathrm{~s} / \mathrm{d} \quad 5.150 .740$ & 6 & 18,75 \\
\hline 2. & $5.150 .741 \mathrm{~s} / \mathrm{d} \quad 8.743 .037$ & 8 & 25,00 \\
\hline 3. & $8.743 .038 \mathrm{~s} / \mathrm{d} 12.335 .334$ & 5 & 15,63 \\
\hline 4. & $12.335 .335 \mathrm{~s} / \mathrm{d} 15.927 .631$ & 6 & 18,75 \\
\hline 5. & $15.927 .632 \mathrm{~s} / \mathrm{d} 19.519 .928$ & 3 & 9,38 \\
\hline 6. & 19.519 .929 s/d 23.112.225 & 4 & 12,50 \\
\hline & Jumlah & 32 & 100,00 \\
\hline
\end{tabular}

Sumber: Data Primer diolah, 2020

Berdasar Tabel 7. Terdapat enam rentang pendapatan yang membedakan pengrajin tape ketan berdasarkan pendapatan per kapita atas pendapatan total. Terdapat 8 pengrajin atau setara $25,00 \%$ dengan dengan pendapatan per kapita pengrajin tape ketan atas pendapatan total yang berada dalam rentang pendapatan sebesar Rp5.150.741 s/d Rp8.743.037. Jumlah tersebut merupakan jumlah terbanyak dalam rentang pendapatan per kapia atas pendapatan total. Sementara rentang pendapatan per kapita berdasar pendapatan total dengan jumlah responden paling sedikit pendapatan dengan rentang Rp15.927.632 sd Rp19.519.928 dimana hanya ada 2 orang responden pada rentang tersebut. Jika dilihat secara keseluruhan berdasarkan perhitungan pada rata-rata pendapatan per kapita 32 pengrajin tape ketan atas pendapatan total adalah sebesar adalah Rp10.913.545 yang jika dibandingkan dengan UMK Kabupaten Kuningan yang sebesar Rp1.882.642,36, maka sudah jauh melampaui. Sehingga rata-rata pengrajin tape ketan di Kecamatan Cibeureum sudah berada pada kondisi sejahtera.

Tabel 8. Tingkat Kesejahteraan Responden atas Pendapata Total Keluarga

\begin{tabular}{cccc}
\hline No. & Uraian & Jumlah Responden & Persentase \\
\hline 1. & Sejahtera & 31 & 96,87 \\
2. & Tidak Sejahtera & 1 & 3,13 \\
\hline & Jumlah & 32 & 100,00
\end{tabular}

Sumber: Data Primer diolah, 2020 
Persentase tingkat kesejahteraan pengrajin tape ketan berdasar pendapatan per kapita atas pendapatan total tersaji dalam Tabel 8 . Terdapat dua kategori pengrajin tape ketan yakni pengrajin tape ketan yang sudah berada pada kondisi sejahtera dan kondisi belum sejahtera. Sebanyak 1 pengrajin tape ketan atau sebesar $3,13 \%$ yang berada pada kondisi belum sejahtera karena pendapatan per kapita atas pendapatan total satu pengrajin tersebut kurang dari UMK Kabupaten Kuningan. Sementara itu 31 pengrajin tape ketan lainnya atau setara dengan 96,87 \% dapat dinyatakan berada pada kondisi sejahtera karena pendapatan per kapita atas pendapatan total lebih besar dari UMK yang berlaku di Kabupaten Kuningan. Sehingga dapat disimpulkan bahwa sebagian besar pengrajin tape ketan di Kecamatan Cibeureum sudah berada pada kondisi sejahtera berdasarkan pendapatan per kapita atas pendapatan totalnya.

Menurut penelitian Mahila (2017) UMK itu dasar penetapannya berasal dari KHL dimana KHL merupakan syarat atau kondisi minimal seseorang untuk hidup layak. Sehingga UMK bisa dijadikan indikator untuk menilai seseorang sudah sejahtera atau tidak sejahtera. Kesejahteraan dari pengrajin tape ketan di Kecamatan Cibeureum bisa dilihat berdasarkan pendapatan per kapita keluarga responden dibandingkan dengan UMK Kabupaten Kuningan. Berdasarkan pendapatan dari usaha tape ketan hasilnya sebanyak $93,75 \%$ responden berada pada kondisi sejahtera. Sementara itu 96,87\% responden dikatakan sejahtera berdasarkan dari pendapatan total keluarganya. Pendapatan yang diterima dari usaha tape ketan mampu menghidupi keluarga dari pengrajin itu sendiri dan sudah melebihi UMK yang berlaku di Kabupaten Kuningan.

\section{SIMPULAN}

Total biaya rata-rata yang dikeluarkan oleh pengrajin tape ketan di Kecamatan Cibeureum Kabupaten Kuningan yakni sebesar Rp54.285.002, sedangkan total penerimaan rata-rata yang didapat oleh pengrajin tape ketan yakni sebesar Rp87.709.375 sehingga pendapatan rata-rata dari pengrajin tape ketan adalahs sebesar Rp33.424.373 dalam satu bulan. Efisiensi usaha pengrajin tape ketan di Kecamatan Cibeureum Kabupaten Kuningan adalah sebesar 1,62 dimana usaha tape ketan di Kecamatan Cibeureum sudah efisien dan menguntungkan serta layak untuk dikembangkan lebih lanjut. Sebagian besar pengrajin tape ketan di Kecamatan Cibeureun Kabupaten Kuningan dapat dikatakan berada dalam kondisi sejahtera. Terdapat 93,75\% pengrajin tape ketan masuk ke dalam kategori sejahtera berdasarkan pendapatan per kapita keluarga atas usaha tape ketan yang dibandingkan dengan UMK Kabupaten Kuningan. Sementara itu, terdapat $96,87 \%$ pengrajin tape ketan masuk ke dalam kategori sejahtera berdasarkan pendapatan per kapita keluarga atas pendapatan total.
Implikasi dari penelitian ini adalah bagi pihak pengrajin tape ketan, diharapkan dapat memperhatikan faktor-faktor produksi yang digunakan untuk produksi tape ketan agar biaya yang dikeluarkan dapat lebih efisien lagi sehingga pendapatan yang diterima lebih besar. Selain itu, pengrajin tape ketan untuk ke depannya disarankan mulai memasarkan produknya melalui online shop agar jangkauan pemasaran produknya lebih luas. Diharapkan hasil penelitian ini dapat menjadi pertimbangan pemerintah membuat kebijakan dalam hal kontrol harga bahan baku tape ketan, dan mampu menyelenggarakan pendampingan kepada pengrajin seputar pemasaran serta cara produksi yang baik, higienis dan efisien. Bagi pihak lain, semoga hasil penelitian ini dapat dijadikan acuan untuk penelitian selanjutnya di lokasi sama maupun berbeda dengan jangkauan yang lebih luas lagi.

Dalam penelitian ini, variabel yang mempengaruhi efisiensi usaha tape ketan di Kecamatan Cibeureum masih terbatas. Untuk peneltian selanjutnya, diharapkan dapat memperbanyak dan melengkapi kekurangan variabel-variabel yang dapat mempengaruhi tingkat efisiensi usaha tape ketan tersebut. Lokasi penelitian hanya di Kecamatan Cibeureum. Untuk penelitian selanjutnya diharapkan dapat melakukan penelitian di kecamatan lain atau memperluas wilayah penelitian hingga ke tingkat Kabupaten/Kota tertentu.

\section{DAFTAR PUSTAKA}

Arifin, A. (2014). Struktur Industri, Tingkat Produktivitas, dan Efisiensi Ekonomis dalam Pemenuhan Kebutuhan Hidup Layak (Studi Empiris Perajin Tahu Desa Kalisari, Cilongok, Banyumas vs Perajin Tahu Desa Kalikabong, Kalimanah, Purbalingga). Eko-Regional: Jurnal Pembangunan Ekonomi Wilayah, 6(2), 81-90.

Effendi, Sofian. (2012). Metode Penelitian Survei. Jakarta: LP3ES

Kanah, K., Ningrum, E., \& Waluya, B (2015). Tingkat Kesejahteraan Buruh Sadap Karet Ptpn Viii Wangunreja Di Kecamatan Dawuan Kabupaten Subang. Jurnal Geografi Gea, 15(2), 73-83. Doi: https://doi.org/10.17509/gea.v15i2.3550

Mahila, S. (2017). Kebutuhan Hidup Layak dan Pengaruhnya terhadap Penetapan Upah Minimum Provinsi Ditinjau dari Hukum Ketenagakerjaan. Jurnal Ilmiah Universitas Batanghari Jambi, 14(2), 42-51.Doi: http://dx.doi.org/10.33087/jiubj.v14i2.281

Nurhayati, A. (2019). Analisis Kelayakan Usaha Agroindustri Tape Singkong di Desa Candi Binangun Kecamatan Sukorejo Kabupaten Pasuruan. Agroteknika, 2(2), 75-84. Doi: https://doi.org/10.32530/agroteknika.v2i2.38

Rahardi, F. (1999). Agribisnis Tanaman Buah. Penebar Swadaya, Jakarta. 
Rahmawati, I., Sungkawa, I., \& Suciyati, T. (2019). Strategi Pengembangan Usaha Produk Tape Ketan (Kasus di Industri Rumah Tangga Tape Ketan di Kecamatan Cigugur Kabupaten Kuningan). Agrijati Jurnal Ilmiah Ilmu-Ilmu Pertanian. 31(3), 104-118.

Soekartawi. (1995). Analisis Usaha Tani. Universitas Indonesia Press. Jakarta

Suratiyah, K. (2015). Ilmu Usahatani. Penebar Swadaya. Jakarta.

Virginanda, R. R. (2015). Analisis Pengaruh UMK Terhadap Jumlah Tenaga Keja, Kesejahteraan Dan Pertumbuhan Ekonomi. Economics Development Analysis Journal, 4(4), 404-413. Diakses dari https://journal.unnes.ac.id/sju/index.php/edaj/articl e/view/14847 